\title{
Does Ownership Structure Affect Firm Performance in an Emerging Market? The Case of India
}

\author{
Brahmadev Panda* and Dinabandhu Bag
}

\begin{abstract}
Manuscript type: Research paper

Research aim: This study aims to examine the impact of ownership structure (ownership concentration and identities) on the financial and market performance of Indian listed firms, post the US financial crisis 2008.

Design/Methodology/Approach: This study is based on a six-year financial dataset of 100 Bombay Stock Exchange (BSE) listed firms, from FY 2009-10 to FY 2014-15. The study applies the static panel data model (pooled OLS, fixed effect and random effect) and the dynamic panel data model (two-step generalised method of moments) for the hypotheses testing.

Research findings: This study finds that in the case of ownership concentration, large owners have no link with the financial performance. However, they have an adverse impact on the market performance. The presence of promoters, domestic institutions and foreign institutions appears to boost the financial performance, whereas the foreign institutional investment seems to enhance the market performance.
\end{abstract}

\footnotetext{
* Corresponding author: Brahmadev Panda is a Doctoral Research Scholar at the School of Management, National Institute of Technology Rourkela, India. Email: 514sm3009@nit.ac.in, brahmadev.panda@gmail.com

Dinabandhu Bag is working as an Associate Professor at the School of Management, National Institute of Technology Rourkela, India. Email: leepsan@nitrkl.ac.in, dinabandhu.bag@gmail. com
}

Acknowledgement: This research is funded and supported by the Indian Social Science Research (ICSSR), New Delhi, India.

https://doi.org/10.22452/ajba.vol12no1.7 
Theoretical contribution/Originality: The major contributions of this study are the two dimensions of ownership concentration (large owners) and identity (types of owners) being considered as ownership structure, the use of the dynamic panel models to check for the endogeneity issue and the post US financial crisis analysis derived from this study. All of these contribute to the impact of ownership volatility and performance variation in the context of India, thereby making this study a novel one.

Policy implications: Policymakers should consider developing more lucrative policies so as to encourage institutional investors to invest in the Indian market. This is because domestic and foreign institutional owners are central to the enhancement of both the corporate financial and market performance. Further, corporate executives should aim to prevent inefficiencies so as to safeguard the interest of large owners.

Research implications/Limitations: This study has used ownership structure as one of the essential governance mechanisms. Future research may consider other mechanisms like board structure or CEO duality.

Keywords: Ownership Structure, Performance, Panel Data, GMM, Emerging Market

JEL Classification: G32, L25, C33

\section{Introduction}

The role of ownership and its impact on modern organisations and their performance has been a debated topic in financial economics since the early works of Smith (1776). The concept of ownership structure is developed based on the existence of multiple owners or shareholders in modern companies. Berle and Means (1932) attempted to delineate ownership from control in large corporations in the United States, where ownership does not lie in the hand of one person alone, but is instead, disseminated among many persons. The control of these companies, therefore, lies with the managers who represent the interest of the owners in the respective companies (Smith, 1776).

Since the emergence of the concept of diluted ownership, limited ownership rights and the rise of managerial powers in listed companies or firms, the relationship between ownership structure and firm performance has been of great concern. Without the firm owners' proper control, firm performance may decline, and expropriations by managers may rise (Berle \& Means, 1932). Jensen and Meckling (1976) observed 
that managerial ownership could lower agency conflict but increase firm performance. Nonetheless, Shleifer and Vishny (1986, 1997) and Thomsen and Pedersen (2000) explained that strong ownership control is vital for improving firm performance. The ambiguity of the relationship between ownership structure and firm performance has thus instigated the interest of research today as it is very crucial for governance.

Earlier studies (Jensen \& Meckling, 1976; Lichtenberg \& Pushner, 1994; Mehran, 1995) found a monotonic relationship between ownership structure and firm performance. However, there were also studies (Morck, Shleifer, \& Vishny, 1988; McConnell \& Servaes, 1990; Chen, Hexter, \& Hu, 1993; Short \& Keasey, 1999) which found a non-monotonic relationship between the two. All these studies have assumed ownership as the exogenous factor. Nonetheless, Demsetz (1983) and Demsetz and Lehn (1985) challenged the notion. They claimed that ownership structure is an endogenous variable which has no direct relationship on firm performance. Past studies by Demsetz and Villalonga (2001), Farooque, van Zijl, Dunstan and Karim (2007) and Boone, Colombage and Gunasekarage (2011) as well as Loderer and Martin (1997) noted a bidirectional relationship between the two. These results, therefore showed that there is no unanimous conclusion and the debate is still prevailing. Based on this, the current study aims to examine the relationship of these two variables in the context of the Indian public listed companies.

This study attempts to examine the impact of ownership structure on corporate performance in an emerging market scenario, post the US financial crisis of 2008. It is hoped that the outcome can contribute to existing ownership literature in a few ways. First, the ambiguity in the derived inference on the relationship between ownership structure and firm performance, as gathered from extant literature, cannot be generalised. Hence, a further study is inevitable. Second, most of the studies in this line of thought are based on developed markets like the US, the UK and the European community, which may not be applicable in the context of emerging countries such as India, due to different socio-economic and political structures (Fan, Wei, \& Xu, 2011). Unlike their developed counterparts, emerging economies are confronted with a different type of agency problem, where majority of the inside shareholders tend to benefit themselves unfairly. This practice is liklely to disregard the interests of the minority or outside shareholders. Specifically, India has become one of the largest emerging markets in the 
world, where investors across the world are keen to invest in the Indian market. However, the institutional settings and corporate governance of India is different from the developed markets (La Porta, Lopez-deSilanes, \& Shleifer, 1999), making the procedure either more tedious or more difficult. In this regard, information gathered from the current study would be able to provide investors with a better understanding of the Indian market, hence enabling them a better decision making process for investment purposes.

Second, ownership structure in India is typically concentrated on family firms and business groups (Chauhan, Dey, \& Jha, 2016) which are mostly inter-connected either through formal or informal means. In many cases, it is the owners who control these firms through a complicated pyramidal and cross-holding ownerships. This practice allows the owners to own low-equity ownership yet be able to retain a tight control of the firms. In most of the family-owned firms, anyway, the family members are commonly promoted to the upper echelon of the management due to family ties and not merits. These familypromoted upper management members play a central role in the decision-making of the firms. They have the power to transfer resources from one firm to another, as a means to gain private benefits (Cheung, Rau, \& Stouraitis, 2006; Gopalan, Nanda, \& Seru, 2007). Taking this scenario to be typical of developing countries, it would seem that a study on India is thus imperative.

Third, this study takes into account two dimensions of the ownership structure: ownership concentration and identities. Studies (Kogan, Ross, Wang, \& Westerfield, 2006) showed that ownership structure such as non-institutional ownerships and individual ownerships have been minimally regarded before. Individual ownerships or retail investors play a significant role in the capital market. Through their frequent trading, they can positively contribute to the market liquidity and resilience. Evidence also showed (Kogan et al., 2006) that retail investors' trading can have a persistent impact on share prices and market efficiency. Based on this, individual ownership and other types of ownership structure are also included in this study.

Fourth, both the static (pooled OLS, fixed effect and random effect) and dynamic panel models (generalized method of moments - GMM) are employed in this study. The GMM is used to check the endogeneity issue due to the simultaneity bias which exists in the ownership structure. This is rarely used in earlier ownership studies focussing on the Indian context. Fifth, we consider market capitalisation as the 
measure for market performance. This variable is also not considered in earlier studies focussing on the Indian context.

Finally, this study takes into account the US financial crisis of 2008, as one element to understand its effect on Indian corporate performance and ownership variations. The US financial crisis was one of the worst financial epidemics that the world had ever witnessed since the Great Depression of 1930. Undoubtedly, the financial crisis has had a severe impact on investors' sentiment and corporate performance, especially in the context of emerging Asian countries (Kim, Kim, \& Lee, 2015). Based on this, the current study assumes that the post-crisis era can be used to gauge the influence it might have had on the Indian market.

The rest of this paper is structured as follows. Section 2 describes the Indian institutional framework. Section 3 deals with theories and empirical studies related to the ownership structure and its relationship with firm performance, followed by the development of the hypotheses. Section 4 discusses the data, research methodology and model specifications. Section 5 provides the discussion of the empirical results and Section 6 concludes by looking at the limitations and implications.

\section{Literature Review}

\subsection{The Indian Institutional Setting}

The Indian economy has opened up since the structural economic reforms which occurred in 1991, due to the balance of payment crisis. The ambitious plan was launched as a means to attract foreign funds, to privatise the public sector undertakings (PSUs), and to liberalise the stringent rules of India. The impact of the new policy of Liberalisation, Privatisation and Globalisation (LPG), was noticed in the Indian economy in the new millennium. Privatisation led to the transfer of ownerships from the state or central government to the private and public owners (Mukhopadhyay \& Chakraborty, 2017). Similarly, Indian corporate players went public in large numbers, in a bid to attract huge funds so as to compete with the global firms. Consequently, this move diluted the ownership structure of these firms. After the firms became public, there were many players like promoters, management, institutions, foreign investors and corporate players who retained some percentage of the total ownership. The diversification of the ownership structure in the Indian private sector has, inevitably, made governance an emerging issue of concern. 
There are significant discrepancies between the governance systems of the emerging economies and developed economies. India, as an emerging economy, has different institutional settings and regulatory and legal environments in comparison to the developed countries (Prowse, 1992; Krishna, Ojha, \& Barrett, 2017). Therefore, there are certain marked differences in the ownership structure, board structure, business practices, corporate disclosure practices, investor protection laws, governance codes and the market for corporate control. Corporate governance models across the world are different according to the variety of capitalism practised but two popular models stand out. They are the liberal model and the co-ordinate model. The former model prioritises shareholders' interest and it mainly exists in the AngloSaxon countries whereas the latter model acknowledges the benefit of stakeholders and it is mainly found in continental Europe and Japan.

The current institutional framework and regulatory functions of India are adopted from Great Britain due to its colonial past, but the Indian corporate governance model is developed from a mixture of the Anglo-Saxon and German model. In this regard, the Indian corporate sector is further classified into the private sector and the public sector. Much of India's industry is most closely held and dominated by the promoter groups while the public sector companies are mainly monitored by the state or central government. The ownership pattern of both the private and public sector companies was radically altered after the LPG era. The public sector companies became mainly socially driven and this has lowered the profitability and efficiency of the public companies. In contrast, the private sector was primarily driven by the controlling promoter groups (Balasubramanian \& Anand, 2013) with the intention of maximising its benefits. The major issue here is the conflict of interest between the major and minor shareholders of the private companies.

Although India has adopted many governance and regulatory mechanisms from the west, it is still slow in its execution of these rules due to its low political will and insensitive bureaucracy coupled with corruption. The prevalence of the concentrated ownership structure among the large private sector of India has led to a lack of transparency and clarity of its governance and regulatory implementations. Even though India has a market-based system like western countries do, it is still infirm in various areas, for instance, the shortage of an active market for control, the lack of a free flow of information from companies to investors, and the presence of market anomalies. Consequently, the 
ownership structure that prevails among India's corporate sector has become a crucial mechanism for governance.

\subsection{Review of Theory and Empirical Evidence}

The ownership structure is based on the distribution of the equity and property rights of the firms among the shareholders in publicly traded firms. The corporate ownership structure and its relationship with firm performance is developed under the framework of the agency theory (Jensen \& Meckling, 1976) which explains the relationship between the principal and agent, where the agency conflict arises due to the diverging interest between the two coordinating parties (Fama, 1980). Managers of the firms may not work for the best interest of the owners in the absence of their close supervision (Smith, 1776). This will mitigate the profit maximisation purpose of the owners, and also creates doubt on the survival of the firm (Fama, 1980). To alleviate the agency problem and to optimise firm performance, ownership control has become a crucial governance mechanism even though earlier evidence looking at the relationship between ownership structure and performance had been mixed.

\subsubsection{Ownership Concentration and Firm Performance}

The agency theory also delineates the separation of ownership from control, and this leads to the confiscation of property by managers. The dilution of the owners' supervision in the firm boosts managerial opportunism and it can adversely affect firm performance (Berle \& Means, 1932). Owners with small ownership in the firms are not interested in disciplining the blundering managers (Grossman \& Hart, 1980), but owners with concentrated ownership can discipline the managers by utilising their voting rights. Their knowledge and resources can also enhance firm performance (Carney \& Gedajlovic, 2001). Blockholders, with their complete control over the management, can also be helpful for resolving the free rider problem and moral hazards in their firms (Shleifer \& Vishney, 1986), an action which can reduce agency costs.

The survey conducted by La Porta et al. (1999) mentioned that most of the economies of the world have a concentrated ownership structure except for the USA and UK. The study by Shleifer and Vishny (1997) also concluded that ownership concentration prevailed in most of the 
Latin American, European, East Asian and African listed firms, but in Asian countries, the ownership structure was noted to be pyramidal and cross-sectional (Claessens \& Fan, 2002). Studying Japanese companies, Kang and Shivdasani (1995) found that there was a high ownership concentration but Prowse (1992) found that financial institutions were those with the largest shareholders in the Japanese listed firms. In China, most of the firms were of high ownership concentration, with majority of the ownership being in the hands of the government (Xu \& Wang, 1999) but in the case of Germany, large shareholders seemed to control the management of the listed firms (Franks \& Mayer, 2001).

Studies (Berle \& Means, 1932; Jensen \& Meckling, 1976; Shleifer \& Vishny, 1986) have noted that most of the countries' corporate world is dominated by concentrated ownership and large shareholders who controlled the management of the firms so as to maximise their returns. This was verified by Berle and Means (1932) and Jensen and Meckling (1976) who agreed that in a dispersed ownership pattern, ownership concentration can mitigate the agency problem. This helped to enforce firm performance. Shleifer and Vishny (1986) also argued that large shareholders have the capacity to streamline the action of the managers and to motivate them into improving firm performance. This was endorsed by La Porta et al. (1999) who stated that in a country with a less developed capital market and weaker investor protection, ownership concentration is beneficial for improving firm performance.

Thomsen and Pedersen (2000), Gorton and Schmid (2000), Earle, Kucsera and Telegdy (2005), Alonso-Bonis and de Andrés-Alonso (2007) and Krivogorsky and Grudnitski (2010) examined the effects of ownership concentration in the context of European countries. They all documented the positive effects of ownership concentration in their findings. Other studies witnessing the positive effect of ownership concentration on firm performance in other countries can be traced to Javid and Iqbal (2008) who examined Pakistan, $\mathrm{Hu}$ and Izumida (2008) who focussed on Japan, Boone et al. (2011) and Gaur, Bathula and Singh (2015) who examined New Zealand, and Desoky and Mousa (2013) who focussed on Egypt.

Despite this being so, some studies had noted the negative relationship between ownership concentration and firm performance. For instance, Leech and Leahy (1991) observed the ownership concentration of UK listed firms and Agrawal and Knoeber (1996) studied the interdependence of the control mechanisms in 400 of the largest USA firms. Both studies found no empirical relationship between insider 
ownership and firm performance. Similarly, Jiang (2004), Džanić (2012) and Al-Saidi and Al-Shammari (2015) also reported the negative effect of ownership concentration. Investigating the relationship between ownership concentration and firm performance among a sample of USA firms, Demsetz and Villalonga (2001) also concluded that large shareholders were negatively related to firm performance.

Nonetheless, some studies found the inter-deterministic relationship between ownership structure and firm performance. For instance, Demsetz (1983) noted that ownership concentration was considered as the endogenous variable; it had no effect on firm performance. Likewise, Demsetz and Lehn (1985) found the endogeneity between ownership concentration and firm performance in the USA listed firms to be unassociated. The study of Demsetz and Villalonga (2001) also considered ownership structure as an endogenous variable; they stated that there was no significant link between ownership structure and firm performance. Finally, Manawaduge, De Zoysa and Rudkin (2009) looking at Sri Lanka and Al-Saidi and Al-Shammari (2015) looking at Kuwait, also reported no significant association between ownership concentration and firm performance.

\subsubsection{Ownership Identity and Performance}

Ownership identity is the other dimension of the ownership structure observed in the current study. It is a concept which can be described as made up of different types of owners who have a certain percentage of shares in the firms. They thus comprised promoters, corporate investors, financial institutional investors, government bodies, individual investors and employee stock owners (Boone et al., 2011). These ownership types or ownership identities have a different level of behaviour, which signifies the various kinds of engagement that can influence firm performance (Denis \& McConnell, 2003). Ownership identities offer the shareholders three bases of powers, such as formal power, social impact power and expertise in the firms concerned (Kang \& Sørensen, 1999).

In ownership identities, large institutional shareholders have the highest level of motivation, incentive and resources to control the actions of the managers. They can drive managerial behaviour towards improving firm performance by reducing the managers' self-consuming behaviours (McConnell \& Servaes, 1995). In their studies, Leech and Leahy (1991), Xu and Wang (1999) and Al-Khouri (2006) reported that institutional investors have a positive impact on the firm's value. In 
contrast, Agrawal and Knoeber (1996), and La Porta, Lopez-de-Silanes, Shleifer and Vishny (1998) noticed that domestic and institutional investors do not have any effect on firm performance while Barnhart and Rosenstein (1998) detected a negative association between institutional ownership and firm performance. Finally, Cronqvist and Nilsson (2003) found no association.

State ownership or government ownership is the next kind of ownership structure which prevails in most countries across the world. In the case of state-controlled companies, politicians are the ones who select the executives and other personnel, based on politicians' bias, rather than on the selected members credentials. This practice can lead to more transaction costs (Megginson, Nash, \& Van Randenborgh, 1994). The influence of the politicians and bureaucrats in the decisionmaking process is very rampant in government-controlled firms and this unhealthy practice can adversely affect firm performance and firm efficiency (Shleifer \& Vishny, 1994). Focussing on Middle Eastern countries, Aljifri and Moustafa (2007) and Omran, Bolbol and Fatheldin (2008) noted that government ownership has a positive association with firm performance. In contrast, Gunasekarage, Hess and Hu (2007) and Liao, Shyu and Chien (2014) stated that the high level of government ownership adversely affected firm performance in the case of China.

Another type of ownership structure is the founding family investors who try to enhance their interests by side lining the concerns of other shareholders (Morck et al., 1988; Prowse, 1992). In their study, Anderson and Reeb (2003) examined the performance of family-owned and non-family owned firms in the USA. They found that familyowned firms performed better than non-family owned firms. Chu (2011) mentioned that when family members of the firms were also the heads of the business, top executives or were members on the board of directors, the performance of the firms is strong. This claim was endorsed by Barontini and Caprio (2006) who studied ten European countries and were able to show evidence of the positive impact of family control on firm performance. This outcome was also validated by Yammeesri and Lodh (2004) and Shyu (2011) who looked at Taiwanese firms. Nonetheless, Filatotchev, Lien and Peisse (2005) found this not to be true.

Investments can come from any individual or group. Corporate investors, or business entities, for instance, invest with the purpose to control the actions of the managers, and to earn a huge financial gain. They have more inclinations towards earning a profit and in gaining 
information about the firms (La Porta et al., 1999). Researchers like Xu and Wang (1999), Qi, Wu and Zhang (2000) and Hovey, Li and Naughton (2003) mentioned that the presence of corporate investors increased firm's profitability. In the case of individual shareholders, it was observed that their impact on the firm's decision-making process was very limited. This is because individual shareholders do not have the required power or the voting right to monitor the management (Zeitun \& Gang Tian, 2007). Besides individual shareholders, another kind of ownership structure can be traced to managerial ownership. This type of ownership could influence firm performance as noted by Alabdullah (2018). However, Al-Khouri (2006), Džanić (2012) and Muller-Kahle (2015) detected that it had a negative effect on firm performance. Likewise, Liao, Shyu and Chien (2014) also found that managerial ownership had no influence on firm performance in Taiwan. Table 1 shows a summary of the empirical works done on ownership structure and firm performance.

\subsubsection{Evidence from India}

So far, we have witnessed certain studies which had stressed on the effect of the ownership structure on firm performance, whether positively, negatively or neutrally. This section highlights those studies which had focussed on India specifically, as shown in Table 2. In this regard, Ganguli and Agrawal (2009) mentioned that promoters were one of the largest shareholders in India. Their monitoring helped to improve the performance of the Indian companies (Haldar \& Rao, 2011; Manna, Sahu and Gupta 2016; Mishra \& Kapil, 2017). Likewise, Deb and Chaturvedula (2003) and Manna et al. (2016) also detected evidence showing that institutional ownership was positively related to the firm's performance measures. However, Srivastava (2011) stated that promoters have no influence on firm performance.

As noted in the table, empirical works conducted in the context of India are not very widespread. Among these studies, we also identified some limitations within. First, the consideration of ownership concentration in this line of research in the context of India is rather limited. Many of these studies had focussed on the promoters and institutional ownership. Second, earlier studies have not considered the endogeneity issue which exists in the ownership structure. Third, the use of the dynamic panel data methodology was hardly done in earlier works. Fourth, a post-US financial crisis had not been considered 
Brahmadev Panda and Dinabandhu Bag

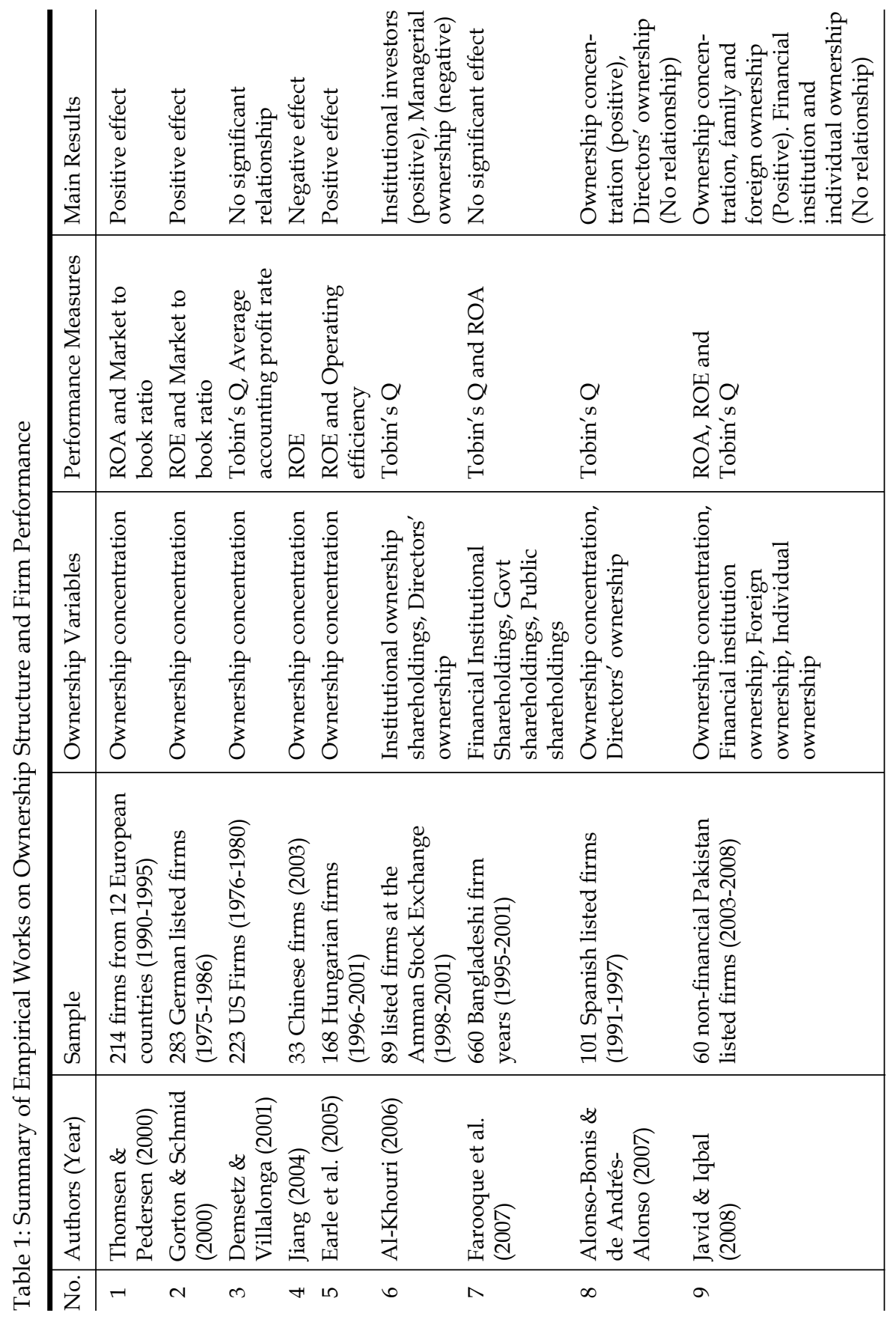




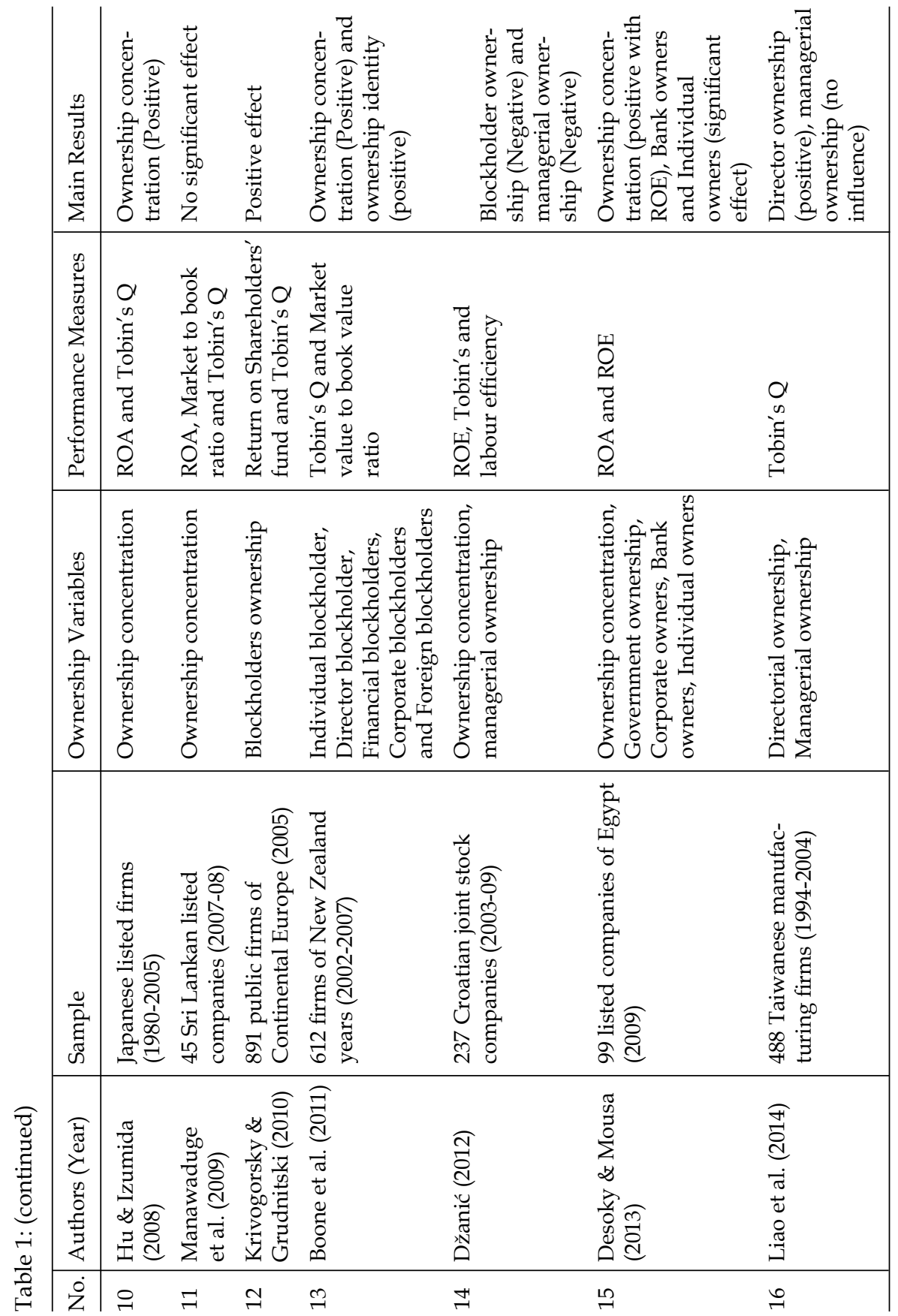


Brahmadev Panda and Dinabandhu Bag
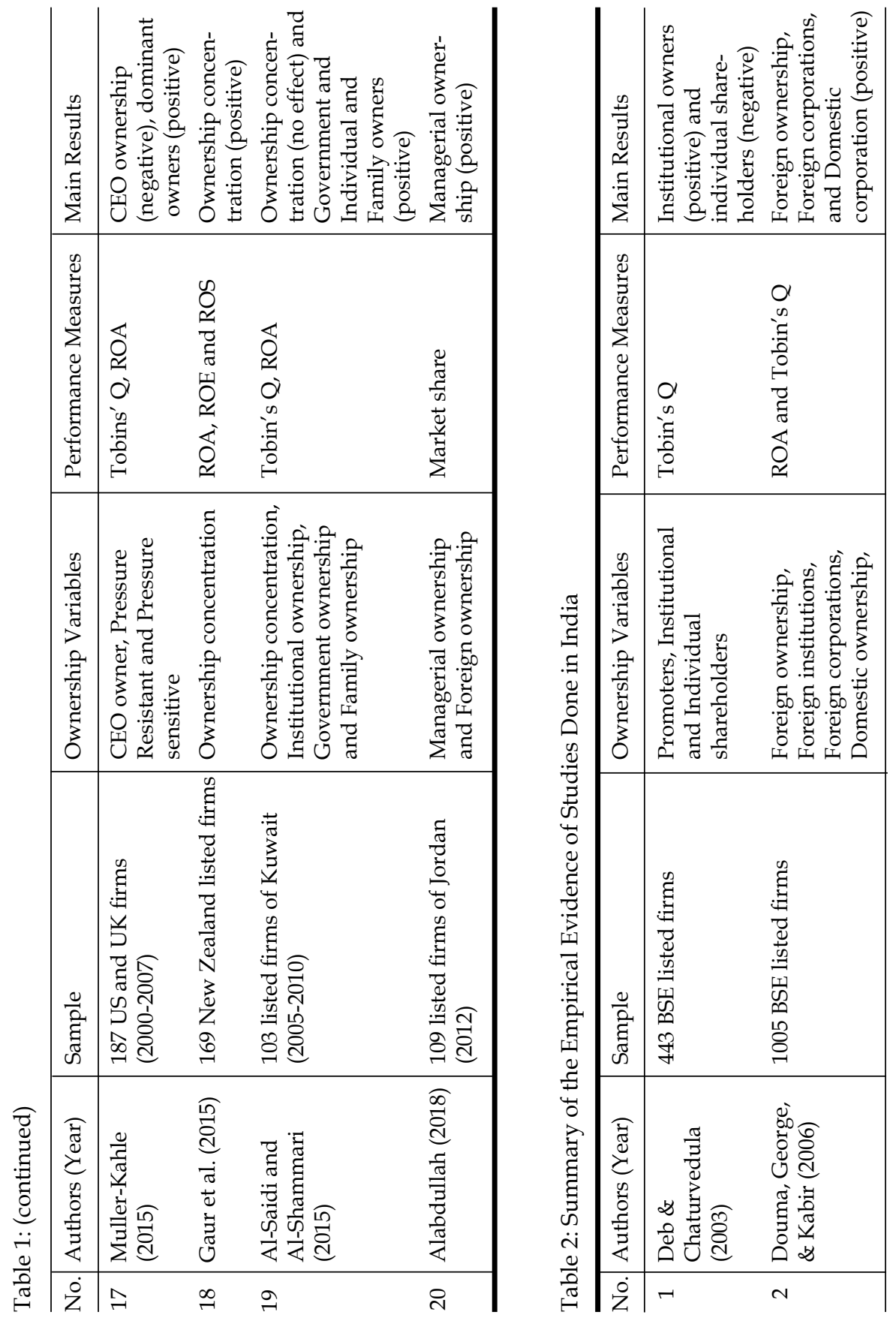


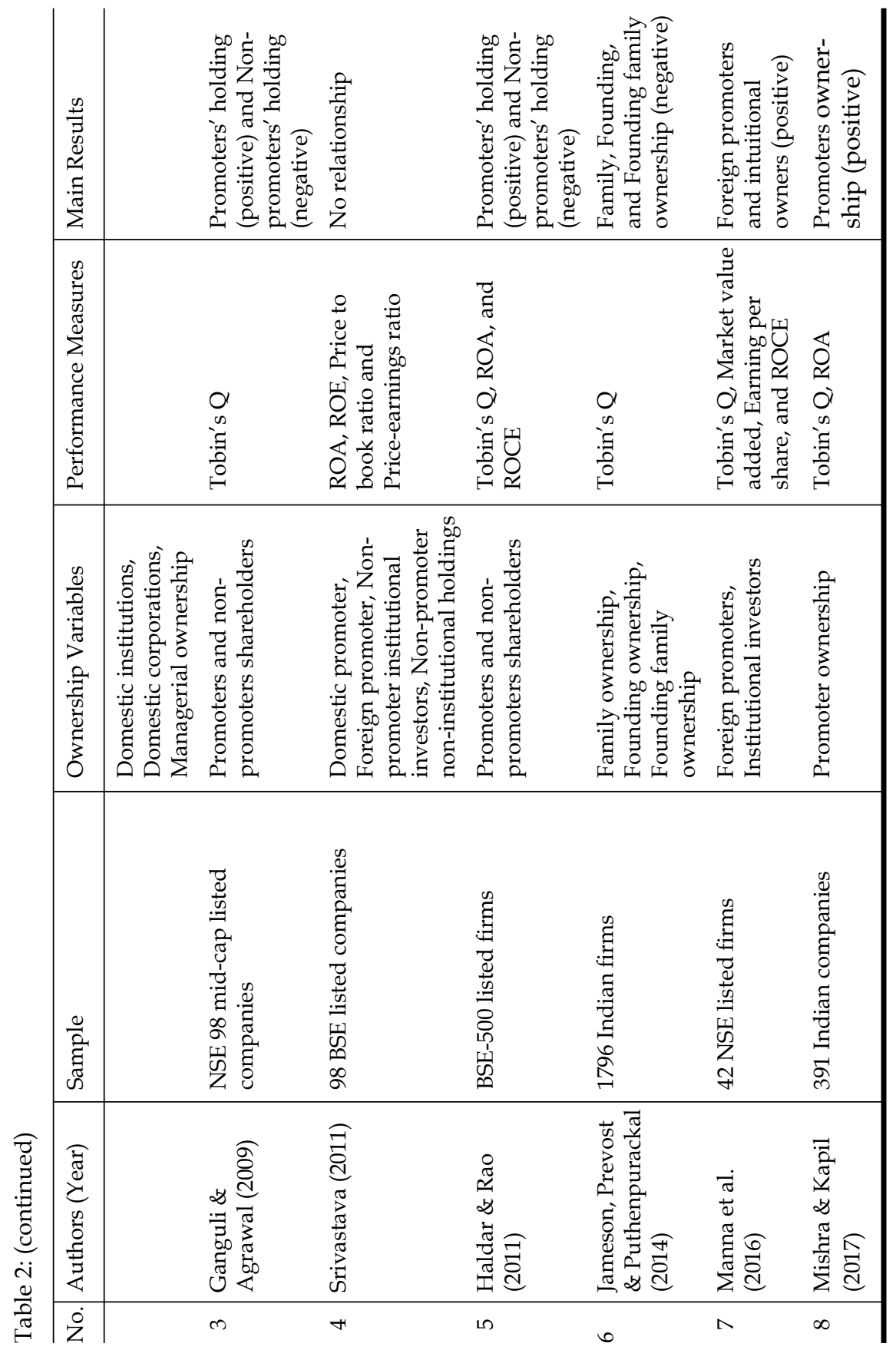


in those studies. The use of the agency theory in these studies had also conceptualised that the ownership structure enhances firm performance by mitigating the agency problems (Jensen \& Meckling, 1976; Fama, 1980). Based on this philosophy, we predict that ownership structure has a positive and significant effect on firm performance. We consider ownership concentration and ownership identities as two dimensions of the ownership structure (Denis \& McConnell, 2003). Further, firm or corporate performance is segregated into two categories: financial performance and market performance. Based on the review of previous literature mentioned, we hypothesised that:

$\mathrm{H}_{1}$ : Ownership concentration has a significant positive impact on the financial performance of the Indian listed firms, after the US financial crisis.

$\mathrm{H}_{2}$ : Ownership identities have a significant positive impact on the financial performance of the Indian listed firms, after the US financial crisis.

$\mathrm{H}_{3}$ : Ownership concentration has a significant positive impact on the market performance of the Indian listed firms, after the US financial crisis.

$\mathrm{H}_{4}$ : Ownership identities have a significant positive impact on the market performance of the Indian listed firms, after the US financial crisis.

\section{Data and Methodology}

\subsection{Sample}

This study selected the largest 100 firms from the Bombay Stock Exchange (BSE) and data over a period of six years from financial year 2009-10 to financial year 2014-15 are used to test the hypotheses. The BSE is the largest and oldest stock exchange of India which has been in operation since 1875. As of August 2016, more than 5500 companies are listed on the BSE. In this study, the BSE-100 companies are selected due to their total market capitalisation, that is, 67 per cent of the total market capitalisation of the BSE. This signifies that the BSE-100 companies represent almost 70 per cent of the BSE (International Finance Corporation, 2018). Further, we develop this study by using data that exist after the US financial crisis of 2008, so as to gauge the impact of the crisis on the variations of firm/corporate performance and ownership 
patterns. We then form two models in this study. The first model is developed to uncover the causal relationship between ownership concentration and firm/corporate performance, where the sample comprised 91 BSE listed firms. The second model discusses the impact of the ownership identities on firm/corporate performance, where 93 listed companies are finalised as samples. The data involving firm/corporate performance, ownership structure, and firm-specific variables, are collected from the PROWESS database of CMIE (Centre for Monitoring the Indian Economy).

\subsection{Measurement Variables}

This study applies two dependent variables - return on assets (ROA) and market capitalisation (MC) as proxies for the financial performance and market performance, respectively. These two performance measures - ROA and MC, are taken from previous literature (Thomsen \& Pedersen, 2000; Farooque et al., 2007; Haldar \& Rao, 2011; Al Mubarak \& Hamdan, 2016). Two broad independent variables are used for the ownership structure: ownership concentration and ownership identities. The first of these, ownership concentration, is measured by the percentage of the shareholdings of the largest shareholder (C1) and the top five largest shareholders (C5), as noted in the works of Demsetz and Villalonga (2001), Jiang (2004), Earle et al. (2005), and Desoky and Mousa (2013). The ownership identities are next categorised into five variables: promoter holdings (POWN), domestic institutional owners (DIO), foreign institutional owners (FIO), non-institutional owners (NIO), and individual owners (IO). These ownership identity variables are derived from previous literature (Deb \& Chaturvedula, 2003; Javid \& Iqbal, 2008).

\subsection{Control Variables}

Several control variables are also considered in this study so as to adjust for the economic and industry effects which explain the firm's performance significantly. Firm-specific variables like firm age (FA), firm size (SZ), leverage (LEV), asset turnover ratio (ATR) and liquidity (LIQ) are also taken into account. Firm age is represented by the number of years of the firm's incorporation. Firm size is considered as one of the important firm-specific factors which has a significant impact on firm performance (Džanić, 2012). Firm size is included in the empirical model to control the size effect across the firms. This is because the size of the 
firms can determine if firms get to enjoy the economies of scale and scope. In the current study, we use the natural logarithm of total assets of the firm as a proxy for firm size (Džanić, 2012; Alipour, 2013). The leverage is incorporated because debt disciplines the managers which then reduces the agency cost and improves the firm's performance positively (Park \& Jang, 2010). The assets turnover ratio indicates how the firms utilise their assets to generate revenue. A better utilisation ratio leads to a better performance (Welch, 2003). Liquidity is measured by the ratio between current assets and current liabilities, and higher liquidity leads to better firm performance (Alipour, 2013).

\subsection{Methodology}

The data in this study are extracted from the cross-sectional and time series base via the panel data method. The STATA version 12 is used to conduct the panel data analysis so as to examine the impact of the ownership structure on the firm's performance. The panel data method has been used significantly by researchers in the area of financial economics. This is because it captures the individual and time effect of the samples, and it also controls the heterogeneity problem which may exist in the data (Hitt, Gimeno, \& Hoskisson, 1998). Hence, the panel data model is considered to be better than the cross-sectional and timeseries models. In this study, we employed the static and dynamic panel models to test our hypotheses. The static panel data models we used include pooled OLS, fixed effect and random effect. Following this, the three tests comprising the F-test (Baltagi, 1995) is used to choose between the pooled OLS and the fixed effect while the Lagrange multiplier test (Breusch \& Pagan, 1980) is utilised to choose between the pooled OLS and the random effect. Finally, Hausman test (Hausman, 1978) is applied to choose between the fixed effect and the random effect.

In the case of the dynamic panel model, we use a two-step generalized method of moments (GMM) to address the endogeneity issue. The GMM model is helpful in eliminating the endogeneity problem through the internally generated instrumental variables. The Arellano-Bond test is next applied to check the serial correlation problem, where $\mathrm{AR}(1)$ and $\mathrm{AR}(2)$ would indicate the first-order and second-order serial correlation. We use the Sargan test to examine the over-identification and validity of the instruments. The Sargan test, with high p-value approves the validity of the model while the significant p-value of the Wald test implies validity for the overall model. 


\subsection{Model Specification}

The empirical findings are segregated into two sections. The first section deals with the impact of the ownership concentration on firm performance by estimating the following panel data regression model.

$$
\begin{aligned}
& \mathrm{FP}_{i t}=\mathrm{a}+\beta 1 \mathrm{C1} 1_{i t}+\beta 2 \mathrm{C5}_{i t}+\beta 3 \mathrm{FA}_{i t}+\beta 4 \mathrm{FS}_{i t}+\beta 5 \mathrm{LEV}_{i t}+ \\
& \beta 6 \mathrm{ATR}_{i t}+\beta 7 \mathrm{LIQ}_{i t}+\varepsilon_{i t} \\
& \mathrm{MP}_{i t}=\alpha+\beta 1 C 1_{i t}+\beta 2 \mathrm{C5}_{i t}+\beta 3 \mathrm{FA}_{i t}+\beta 4 \mathrm{FS}_{i t}+\beta 5 \mathrm{LEV}_{i t}+ \\
& \beta 6 \mathrm{ATR}_{i t}+\beta 7 \mathrm{LIQ}_{i t}+\varepsilon_{i t}
\end{aligned}
$$

where,

$\mathrm{FP}_{i t}=$ Financial performance represented by return on assets

$\mathrm{MP}_{i t}=$ Market performance represented by market capitalisation

$\mathrm{Cl}_{i t}=$ Shareholdings of the single largest shareholder

$\mathrm{C5}_{i t}=$ Shareholdings of the top five largest shareholders

$\mathrm{FA}_{i t}=$ Firm age

$\mathrm{FS}_{i t}=$ Firm size

$\mathrm{LEV}_{i t}=$ Leverage

$\mathrm{ATR}_{i t}=$ Assets turnover ratio

$\mathrm{LIQ}_{i t}=$ Liquidity

$\varepsilon_{i t} \quad=$ Error term

The second model tests the effect of ownership identities or the types of owners on firm performance by estimating the following panel data regression models, where we have introduced several types of large shareholders.

$$
\begin{aligned}
& \mathrm{FP}_{i t}=\alpha+\beta 1 \mathrm{PO}_{i t}+\beta 2 \mathrm{DIO}_{i t}+\beta 3 \mathrm{FIO}_{i t}+\beta 4 \mathrm{NIO}_{i t}+\beta 5 \mathrm{IO}_{i t}+ \\
& \beta 6 \mathrm{FA}_{i t}+\beta 7 \mathrm{FS}_{i t}+\beta 8 \mathrm{LEV}_{i t}+\beta 9 \mathrm{ATR}_{i t}+\beta 10 \mathrm{LIQ}_{i t}+\varepsilon_{i t} \\
& \mathrm{MP}_{i t}=\alpha+\beta 1 \mathrm{PO}_{i t}+\beta 2 \mathrm{DIO}_{i t}+\beta 3 \mathrm{FIO}_{i t}+\beta 4 \mathrm{NIO}_{i t}+\beta 5 \mathrm{IO}_{i t}+ \\
& \beta 6 \mathrm{FA}_{i t}+\beta 7 \mathrm{FS}_{i t}+\beta 8 \mathrm{LEV}_{i t}+\beta 9 \mathrm{ATR}_{i t}+\beta 10 \mathrm{LIQ}_{i t}+\varepsilon_{i t}
\end{aligned}
$$

where,

$\mathrm{FP}_{i t}=$ Financial performance represented by return on assets

$\mathrm{MP}_{i t}=$ Market performance represented by market capitalization

$\mathrm{PO}_{i t}=$ Promoters ownership holdings

$\mathrm{DIO}_{i t}=$ Domestic institutional owners

$\mathrm{FIO}_{i t}=$ Foreign institutional owners

$\mathrm{NIO}_{i t}=$ Non-institutional owners

$\mathrm{IO}_{i t}=$ Individual owners 
$\mathrm{FA}_{i t}=$ Firm age

$\mathrm{FS}_{i t}=$ Firm size

$\mathrm{LEV}_{i t}=$ Leverage

$\mathrm{ATR}_{i t}=$ Assets turnover ratio

$\mathrm{LIQ}_{i t}=$ Liquidity

$\varepsilon_{i t} \quad=$ Error term

Table 3 is provided to highlight the summary of the variables used in the current study.

Table 3: Summary of the Variables

\begin{tabular}{|c|c|c|c|}
\hline Variables & Definition & Symbol & Type \\
\hline Return on assets & EBIT/total assets & ROA & Dependent \\
\hline Market capitalisation & $\begin{array}{l}\text { Natural log of market } \\
\text { capitalisation }\end{array}$ & $\mathrm{MC}$ & Dependent \\
\hline $\begin{array}{l}\text { Ownership } \\
\text { concentration }\end{array}$ & $\begin{array}{l}\text { Percentage of shareholdings } \\
\text { by the single largest and five } \\
\text { largest shareholders }\end{array}$ & $\mathrm{C} 1, \mathrm{C} 5$ & Independent \\
\hline Promoters' ownership & $\begin{array}{l}\text { Percentage of shareholdings } \\
\text { by promoters }\end{array}$ & POWN & Independent \\
\hline $\begin{array}{l}\text { Domestic institutional } \\
\text { ownership }\end{array}$ & $\begin{array}{l}\text { Percentage of shareholdings } \\
\text { by Indian institutional } \\
\text { investors }\end{array}$ & $\mathrm{DIO}$ & Independent \\
\hline $\begin{array}{l}\text { Foreign institutional } \\
\text { ownership }\end{array}$ & $\begin{array}{l}\text { Percentage of shareholdings } \\
\text { by foreign institutional } \\
\text { investors }\end{array}$ & FIO & Independent \\
\hline $\begin{array}{l}\text { Non-institutional } \\
\text { ownership }\end{array}$ & $\begin{array}{l}\text { Percentage of shareholdings } \\
\text { of non-institutional investors }\end{array}$ & NII & Independent \\
\hline Individual ownership & $\begin{array}{l}\text { Percentage of shareholdings } \\
\text { of individual shareholders }\end{array}$ & II & Independent \\
\hline Firm age & $\begin{array}{l}\text { Natural Logarithm of years } \\
\text { since firms' incorporation }\end{array}$ & FA & Control \\
\hline Firm size & $\begin{array}{l}\text { Natural logarithm of } \\
\text { total assets }\end{array}$ & SZ & Control \\
\hline Leverage & $\begin{array}{l}\text { Total outsiders' debt to } \\
\text { total assets }\end{array}$ & LEV & Control \\
\hline Assets turnover ratio & $\begin{array}{l}\text { Total net sales/total fixed } \\
\text { assets }\end{array}$ & ATR & Control \\
\hline Liquidity & Current ratio/current assets & LIQ & Control \\
\hline
\end{tabular}




\section{Results and Discussions}

The results of the study are also classified into two sub-sections. The first sub-section presents and discusses the univariate and multivariate results derived from the empirical tests which examined the relationship between the ownership concentration and firm performance. The next sub-section deals with the empirical results obtained from the tests conducted on the relationship between the ownership identities and firm performance.

\subsection{Ownership Concentration and Performance}

Literature focusing on the relationship between ownership concentration and firm performance has been very diverse. Some like Gorton and Schmid (2000), Earle et al. (2005), Hu and Izumida (2008), Desoky and Mousa (2013) noted that ownership concentration has a positive impact. Others like Demsetz and Villalonga (2001), Jiang (2004), Manawaduge et al. (2009), and Fauzi and Locke (2012) found that ownership concentration has a negative impact on firm performance. Both the groups were divergent in their findings. Therefore, in this study, we attempt to test the relationship between ownership concentration and firm performance, in the context of an emerging market like India, post the US financial crisis of 2008. This sub-section, therefore, presents the descriptive statistics, correlation matrix, static and dynamic panel data models results, which were derived from the model used to examine the relationship between ownership concentration and firm performance. Table 4 further illustrates.

Table 4: Descriptive Statistics

\begin{tabular}{lrrrcc}
\hline Variable & Mean & Minimum & Maximum & $\begin{array}{c}\text { Standard } \\
\text { Deviation }\end{array}$ & $\begin{array}{c}\text { Total } \\
\text { Observation }\end{array}$ \\
\hline ROA & 8.926 & -47.11 & 60.42 & 9.254 & 546 \\
MC & 12.676 & 4.54 & 15.42 & 1.101 & 546 \\
C1 & 0.403 & 0.04 & 0.90 & 0.218 & 546 \\
C5 & 0.598 & 0.11 & 0.98 & 0.202 & 546 \\
FA & 3.603 & 1.79 & 4.79 & 0.642 & 546 \\
FS & 10.131 & 4.50 & 14.63 & 1.658 & 546 \\
LEV & 0.521 & 0.00 & 1.56 & 0.408 & 546 \\
ATR & 14.368 & 0.28 & 378.58 & 35.187 & 546 \\
LIQ & 1.969 & 0.26 & 17.80 & 2.004 & 546 \\
\hline
\end{tabular}


The statistics given above are derived from the descriptive statistics of the dependent variables (ROA and $M C$ ), the independent variable (C1 and C5), and the control variables (FA, FS, LEV, ATR and LIQ). There is a total of 546 firm-year observations encompassing 91 Indian listed firms which are observed for six years, from FY 2009-10 to FY 2014-15. This offered a longitudinal dimension into understanding the data set.

Table 5 provides the statistics of the independent and dependent variables. Here it can be seen that the financial performance (ROA) and ownership concentration (L1 and L5) have declined consistently since FY 2009-10. This is a sign indicating the adverse effect of the crisis on the Indian corporate market. The average ownership holdings of the single largest and the five largest shareholders, are 40 per cent and 60 per cent, respectively. This outcome is similar to the concentration level of the Chinese listed firms noted by Wang, Guthrie and Xiao (2012). In developed countries like the USA and UK, the ownership structure is observed to be more or less dispersed, as compared to the European and Asian countries (Shleifer \& Vishny, 1986). This was also noted by La Porta et al. (1998) who asserted that the high ownership concentration had become an alternative control mechanism due to low investors' protection rights in the developing countries.

Table 5: Year-wise Data of Dependent and Independent Variables

\begin{tabular}{lcrrrrr}
\hline Variables/FY & $2009-10$ & $2010-11$ & $2011-12$ & $2012-13$ & $2013-14$ & $2014-15$ \\
\hline ROA & 10.00 & 9.58 & 8.68 & 8.33 & 8.26 & 8.34 \\
MC & 12.43 & 12.60 & 12.59 & 12.64 & 12.78 & 13.05 \\
L1 & 40.85 & 41.36 & 41.34 & 39.92 & 39.70 & 39.65 \\
L5 & 60.42 & 60.96 & 60.65 & 59.12 & 58.07 & 58.93 \\
\hline
\end{tabular}

Table 6 presents the correlation matrix and the variance inflation factor value (VIF) of the independent and control variables. The correlation matrix table shows that no variables are having a high correlation coefficient, and this signifies that there is no collinearity problem. The ownership concentration variable of $\mathrm{C} 1$ shows a significant positive correlation with $\mathrm{MC}$, and this implies that an increase in large owner's shareholdings enhances the MC. Next, we find that C5 displays a significant positive association with the ROA, and this signifies that that profitability has improved with an increase in the concentration level. Further, we find that firm size (SZ), leverage (LEV) and assets 
Table 6: Correlation Matrix

\begin{tabular}{|c|c|c|c|c|c|c|c|c|c|c|}
\hline Variables & ROA & $\mathrm{MC}$ & $\mathrm{C} 1$ & C5 & FA & FS & DR & ATR & LIQ & VIF \\
\hline ROA & 1.000 & & & & & & & & & \\
\hline MC & 0.179 & 1.000 & & & & & & & & \\
\hline $\mathrm{C} 1$ & 0.053 & 0.121 & 1.000 & & & & & & & 2.98 \\
\hline C5 & 0.104 & 0.055 & 0.803 & 1.000 & & & & & & 2.88 \\
\hline FA & 0.071 & 0.042 & 0.040 & 0.021 & 1.000 & & & & & 1.11 \\
\hline FS & -0.469 & 0.496 & 0.174 & 0.077 & 0.099 & 1.000 & & & & 1.10 \\
\hline LEV & -0.206 & -0.052 & -0.019 & -0.014 & 0.097 & 0.076 & 1.000 & & & 1.09 \\
\hline ATR & -0.131 & -0.045 & 0.165 & 0.093 & -0.057 & 0.202 & 0.182 & 1.000 & & 1.08 \\
\hline LIQ & 0.177 & 0.115 & 0.153 & 0.168 & 0.148 & 0.123 & -0.136 & 0.032 & 1.000 & 1.06 \\
\hline
\end{tabular}

Note: All correlations in bold are significant at $\mathrm{p}<.05$

turnover ratio (ATR) also have a significant negative correlation whereas liquidity (LIQ) has a positive association with the ROA. In addition, firm size (SZ) and liquidity (LIQ) have a significant positive relationship with MC. Thus, it seems evident from the VIF values that there is no multicollinearity problem as the VIF values of the independent and control variables are under the recommended value of 10 (Kennedy, 2008).

Table 7 shows the Breusch-Pagan test, where we find the chi-square value to have a significant $\mathrm{p}$-value, which signifies that the variables are not homoscedastic. To control the heteroskedasticity and autocorrelation problem, we then use the "clustered" function in the static models employed for this study.

Table 7: Breusch-Pagan Test for Heteroscedasticity

Variables: C1 C5 FA FS LEV ATR LIQ

H0: Constant variance

Chi-square value $\quad 97.51 \quad$ P-value 0.000

Table 8 depicts eight models which comprise of four static models and four dynamic models. The static panel models are the fixed effect models, as confirmed by the specification tests as noted in Table 9. The four dynamic panel models comprise the two-step generalized method of moments (GMM). Here, the serial correlation test results such as the $A R(1)$ and AR(2) show an insignificant p-value for all the GMM models. This indicate that there is no serial correlation problem. Subsequently, 
Brahmadev Panda and Dinabandhu Bag

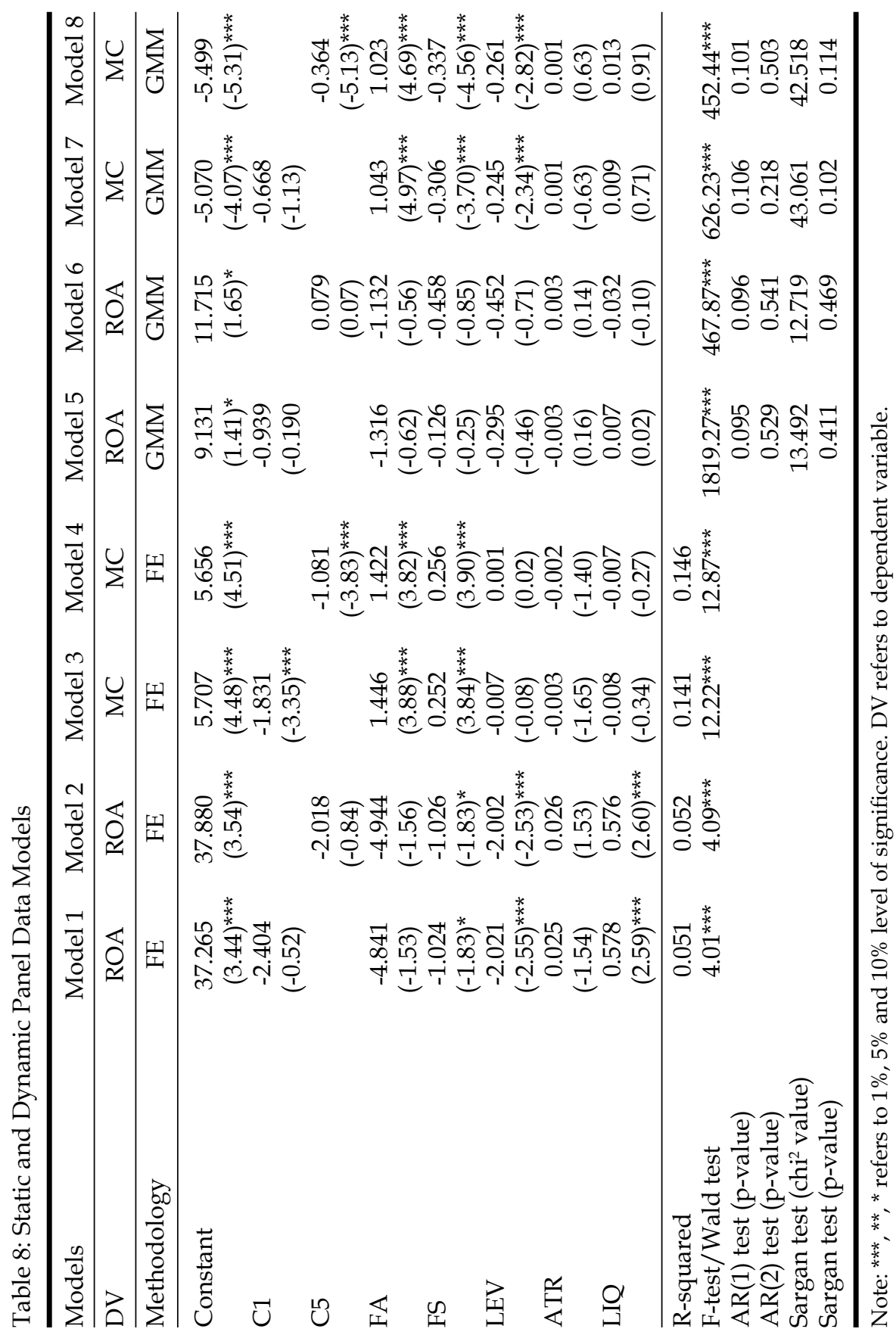


Table 9: Model Optimal Test

\begin{tabular}{lccc}
\hline Models & F-test & LM test & Hausman test \\
\hline Model 1 & $12.30^{* * *}$ & $549.22^{* * *}$ & $14.74^{* *}$ \\
Model 2 & $12.32^{* * *}$ & $544.23^{* * *}$ & $16.11^{* * *}$ \\
Model 3 & $13.71^{* * *}$ & $578.34^{* * *}$ & $29.22^{* * *}$ \\
Model 4 & $13.90^{* * *}$ & $580.34^{* * *}$ & $25.54^{* * *}$ \\
\hline
\end{tabular}

Note: $* * *, * *, *$ refers to $1 \%, 5 \%$ and $10 \%$ level of significance respectively.

the insignificant p-values of the Sargan test imply that the GMM models are free from the over-identification problem.

Table 9 presents the model specification tests which include the F-test, LM test and Hausman test. A significant F-test signifies that the fixed effect is better than the pooled OLS; a significant LM test also imply that the random effect is better than the pooled OLS, and finally, a significant Hausman test would indicate that the fixed effect is better than the random effect.

In this section, we report on both the static and dynamic panel models (Table 8 ) for robustness of the findings. In addition, the findings derived from the dynamic models are also considered. We find that both the ownership concentration variables ( $\mathrm{C} 1$ and $\mathrm{C} 5)$ have no significant impact on the financial performance (ROA) and this signifies that large owners do not influence the Indian firms' corporate financial performance. This result is very much, in line with the findings of Demsetz and Villalonga (2001), Jiang (2004), Demsetz and Lehn (1985) and Fauzi and Locke (2012). Nevertheless, variations noted in ownership concentration levels are observed to have a significant negative influence on market performance (MC), and this signifies that an increase in large ownership holdings has an adverse effect on market sentiments of Indian listed firms. The firm-specific variables, such as firm size and leverage, are noted to have a significant negative effect on market performance. Thus, our findings are consistent with Kapopoulos and Lazaretou (2007), Džanić (2012) and Muller-Kahle (2015).

\subsection{Ownership Identities and Firm Performance}

Earlier studies (Denis \& McConnell, 2003; Boone, et al., 2011; Desoky \& Mousa, 2013) have provided evidence to show that ownership identities have a significant influence on the firms' decision-making process, 
which affected firm performance. The ownership identities of the current study are categorised into five groups: promoters (POWN), domestic institutional owners (DIO), foreign institutional owners (FIO), noninstitutional owners (NIO) and individual owners (IO). The promoters group includes the shareholdings of domestic and foreign promoters. The domestic institutional owners include the shareholdings of mutual funds, insurance companies, as well as banks and financial institutions from India. The foreign institutional owners include investments from banks, insurance companies, and financial institutions from outside India and the Non-institutional owners include investments from the various corporate houses. Finally, the individual investors include total investments from all the retail investors.

Table 10 presents the descriptive statistics of the dependent, independent and control variables. There is a total of 558 firm-year observations, which consist of 93 Indian listed firms observed for six years, from FY 2009-10 to FY 2014-15. The average promoters holding in the samples are very high with 50 per cent stakeholdings, which is similar to the study of Deb and Chaturvedula (2003), also in the Indian context. It is found that the average promoters' holding of the CNX 500 companies is around 52 per cent. In this study, the results show that the average foreign institutional shareholdings (FIO) is almost 20 per cent, and this figure seems to be better than the average shareholdings of

Table 10: Descriptive Statistics

\begin{tabular}{lrrrcc}
\hline Variables & Mean & Minimum & Maximum & $\begin{array}{c}\text { Standard } \\
\text { Deviation }\end{array}$ & $\begin{array}{c}\text { Total } \\
\text { Observation }\end{array}$ \\
\hline ROA & 8.98 & -47.11 & 60.42 & 9.38 & 558 \\
MC & 12.662 & 4.54 & 15.42 & 1.157 & 558 \\
POWN & 0.502 & 0.01 & 0.90 & 0.207 & 558 \\
DIO & 0.12 & 0 & 0.39 & 0.08 & 558 \\
FIO & 0.19 & 0.01 & 0.80 & 0.124 & 558 \\
NIO & 0.145 & 0.01 & 0.50 & 0.088 & 558 \\
IO & 0.086 & 0.01 & 0.25 & 0.055 & 558 \\
FA & 3.572 & 1.79 & 4.79 & 0.631 & 558 \\
SZ & 10.13 & 4.50 & 14.63 & 1.64 & 558 \\
LEV & 0.53 & 0.01 & 5.08 & 0.40 & 558 \\
ATR & 14.11 & 0.12 & 378.58 & 34.85 & 558 \\
LIQ & 1.91 & 0.26 & 17.80 & 1.96 & 558 \\
\hline
\end{tabular}


domestic institutional owners (DIO). The maximum foreign institutional equity investment is nearly 80 per cent whereas the maximum domestic institutional investment is 39 per cent, and this statistic suggests that the Indian listed firms are quite inclined towards foreign investments. The average non-institutional shareholding is only 15 per cent, with a maximum of 50 per cent. Additionally, Table 10 also indicates the average institutional equity investment to be 30 per cent, and this figure is better than the average non-institutional investments. The outcome of this table further demonstrates that the institutional equity investment plays a significant role in the equity ownership structure of the larger Indian firms. The average individual investor's shareholdings (II) in the Indian listed firms is 9 per cent, and this is considered low as the average individual shareholdings of the CNX 500 companies as reported by Deb and Chaturvedula (2003) was 35 per cent.

Table 11 highlights the year-wise data of the dependent and independent variables. Our results indicate that the ownership holdings of the promoters, domestic institutions, non-institutions and individual investors have shrunk continuously since FY 2009-10. This occurrence indicates that the crisis has a harmful effect on the investors' sentiments. Nonetheless, the investments from foreign institutions has increased steadily since FY 2009-10. This occurrence can be inferred as showing that the foreign institutions have shown a strong confidence in the Indian market.

Table 11: Year-wise Data of Dependent and Independent Variables

\begin{tabular}{lrrrrrr}
\hline Variables/FY & $2009-10$ & $2010-11$ & $2011-12$ & $2012-13$ & $2013-14$ & $2014-15$ \\
\hline ROA & 10.00 & 9.58 & 8.68 & 8.33 & 8.26 & 8.34 \\
MC & 12.43 & 12.60 & 12.59 & 12.64 & 12.78 & 13.05 \\
POWN & 50.98 & 50.83 & 50.91 & 50.25 & 49.56 & 48.92 \\
DIO & 13.42 & 12.58 & 12.47 & 11.51 & 11.11 & 11.45 \\
FIO & 17.09 & 18.17 & 18.81 & 20.83 & 21.74 & 21.74 \\
NIO & 14.98 & 15.18 & 14.85 & 14.68 & 14.41 & 13.83 \\
IO & 9.01 & 8.99 & 8.80 & 8.69 & 8.43 & 8.18 \\
\hline
\end{tabular}

Table 12 depicts the correlation coefficients and variance inflation factor (VIF) value of the independent and control variables. From the statistics shown, it is observed that foreign institutional ownership is negatively correlated with ROA whereas no other ownership identity 
Brahmadev Panda and Dinabandhu Bag

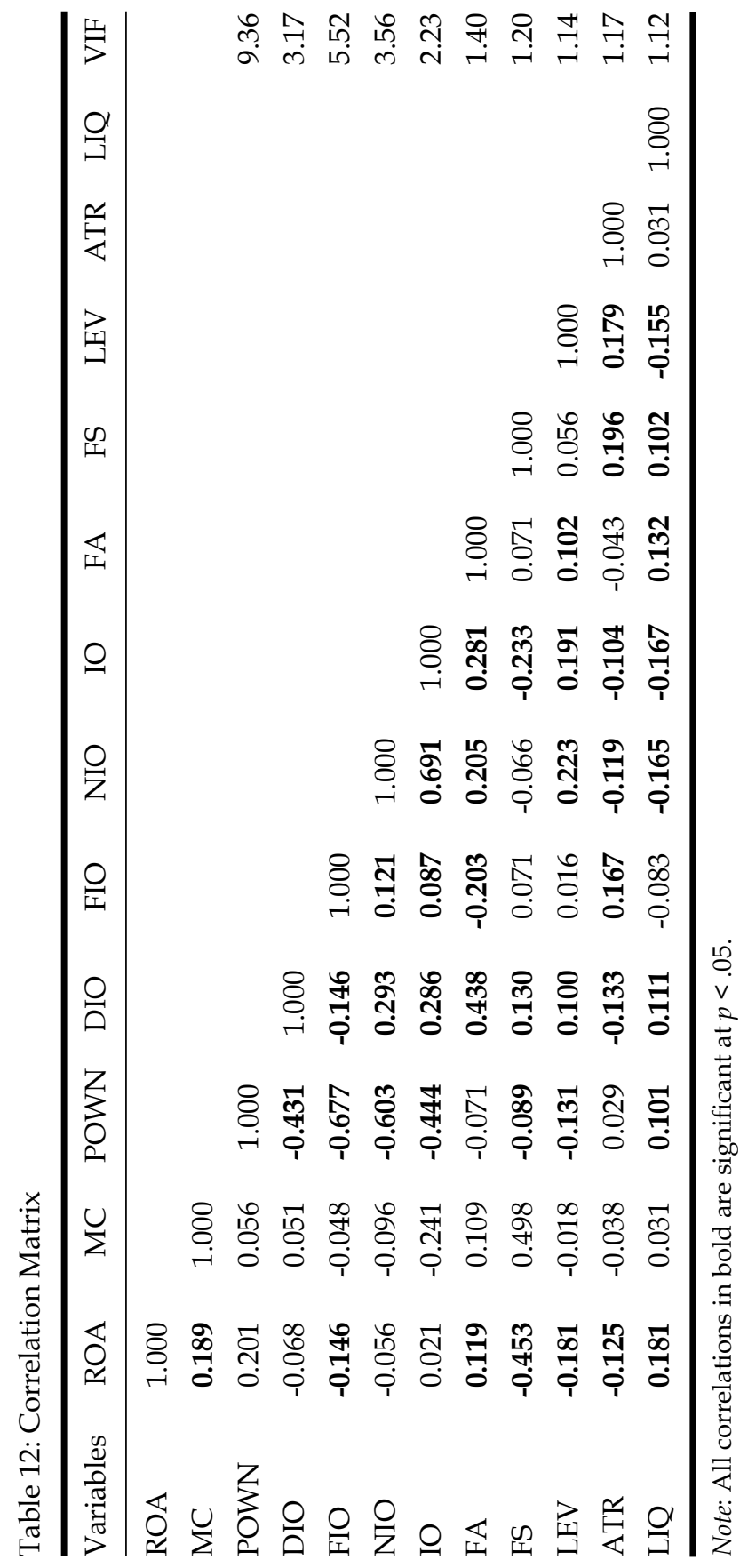


is found to be having a correlation with MC. Further, firm age and liquidity are found to have a positive correlation with ROA while firm size, leverage and asset turnover ratio are found to have a negative correlation with ROA. The correlation coefficients between the variables are not high. In other words, no coefficient has crossed the threshold limit of 0.8 (Kennedy, 2008) and this implies that there is no collinearity problem. Subsequently, there is also no multicollinearity problem within the variables as the VIF values of the variables are under the value of 10 (Kennedy, 2008).

Table 13 shows the Breusch-Pagan test which is used to check the heteroscedasticity problem among the independent and control variables. Here, we find that there is a heteroscedasticity problem with the data as the $p$ value is very significant. In this regard, we used the "clustered" function, together with the static models, to filter the heteroscedasticity and autocorrelation problem.

Table 13: Breusch-Pagan Test for Heteroscedasticity

Variables: POWN, DIO, FIO, NIO, IO, FA, FS, LEV, ATR, LIQ

$\mathrm{H} 0$ : Constant variance

Chi-square value

128.90

P-value 0.000

Table 14 presents the model optimal tests where it is confirmed that both the static models are supported by the fixed effect parameters. Further, the autocorrelation tests $\operatorname{AR}(1)$ and $\operatorname{AR}(2)$ show a higher p-value. This indicates that the GMM models have no autocorrelation problem. We also found no over-identification problem in the GMM models as the p-values of the Sargan test are highly insignificant. Both the F-test and the Wald test are highly significant, with a 1 per cent level of significance. This indicates that the overall model is fit.

Table 14: Model Optimal Test

\begin{tabular}{lccc}
\hline Models & F-test & LM test & Hausman test \\
\hline Model 1 & $14.49^{* * *}$ & $617.90^{* * *}$ & $19.15^{* *}$ \\
Model 2 & $26.62^{* * *}$ & $680.39^{* * *}$ & $510.58^{* * *}$ \\
\hline
\end{tabular}

Note: ${ }^{* * *}{ }^{* *}$ and $*$ refers to $1 \%, 5 \%$ and $10 \%$ level of significance respectively. 
Table 15 exhibits the four models consisting of two static panels and two dynamic panel models. Although we have reported the results derived from both the static and dynamic models (Table 15), our findings have been mostly based on the dynamic panel models.

Table 15: Static and Dynamic Panel Data Models

\begin{tabular}{|c|c|c|c|c|}
\hline Models & Model 1 & Model 2 & Model 3 & Model 4 \\
\hline DV & ROA & MC & ROA & MC \\
\hline Methodology & $\mathrm{FE}$ & $\mathrm{FE}$ & GMM & GMM \\
\hline Intercept & $\begin{array}{c}1.021 \\
(0.07)\end{array}$ & $\begin{array}{c}-0.981 \\
(-0.71)\end{array}$ & $\begin{array}{c}-17.702 \\
(-0.95)\end{array}$ & $\begin{array}{c}-2.228 \\
(-1.30)\end{array}$ \\
\hline POWN & $\begin{array}{l}36.529 \\
(4.99)^{* * *}\end{array}$ & $\begin{array}{c}8.362 \\
(11.71)^{\star * *}\end{array}$ & $\begin{array}{l}33.429 \\
(2.41)^{* * *}\end{array}$ & $\begin{array}{c}0.724 \\
(0.47)\end{array}$ \\
\hline $\mathrm{DIO}$ & $\begin{array}{l}34.655 \\
(3.96)^{* * *}\end{array}$ & $\begin{array}{c}5.728 \\
(6.72)^{\star * *}\end{array}$ & $\begin{array}{l}25.011 \\
(2.01)^{* *}\end{array}$ & $\begin{array}{c}0.575 \\
(0.37)\end{array}$ \\
\hline FIO & $\begin{array}{l}38.668 \\
(5.72)^{* * *}\end{array}$ & $\begin{array}{c}10.203 \\
(15.50)^{\star * *}\end{array}$ & $\begin{array}{l}23.174 \\
(3.20)^{* * *}\end{array}$ & $\begin{array}{c}2.369 \\
(2.09)^{* *}\end{array}$ \\
\hline $\mathrm{NIO}$ & $\begin{array}{l}28.113 \\
(2.27)^{\star *}\end{array}$ & $\begin{array}{c}7.882 \\
(6.53)^{\star * *}\end{array}$ & $\begin{array}{c}16.125 \\
(1.40)\end{array}$ & $\begin{array}{c}2.091 \\
(1.30)\end{array}$ \\
\hline $\mathrm{IO}$ & $\begin{array}{c}5.245 \\
(0.26)\end{array}$ & $\begin{array}{c}-3.893 \\
(-2.02)^{*}\end{array}$ & $\begin{array}{c}22.802 \\
(0.92)\end{array}$ & $\begin{array}{c}-0.474 \\
(-0.17)\end{array}$ \\
\hline FA & $\begin{array}{c}-5.001 \\
(-1.50)\end{array}$ & $\begin{array}{l}1.138 \\
(3.50)^{\star * *}\end{array}$ & $\begin{array}{c}-1.243 \\
(-0.43)\end{array}$ & $\begin{array}{c}0.255 \\
(0.72)\end{array}$ \\
\hline FS & $\begin{array}{c}-0.941 \\
(-1.71)^{*}\end{array}$ & $\begin{array}{c}0.186 \\
(3.48)^{\star * *}\end{array}$ & $\begin{array}{c}0.056 \\
(0.06)\end{array}$ & $\begin{array}{c}0.186 \\
(1.33)\end{array}$ \\
\hline DR & $\begin{array}{l}-1.786 \\
(-2.35)^{\star * *}\end{array}$ & $\begin{array}{c}-0.001 \\
(-0.01)\end{array}$ & $\begin{array}{c}-0.452 \\
(-0.46)\end{array}$ & $\begin{array}{c}-0.051 \\
(-0.57)\end{array}$ \\
\hline ATR & $\begin{array}{c}0.021 \\
(1.34)\end{array}$ & $\begin{array}{c}-0.002 \\
(-1.60)\end{array}$ & $\begin{array}{c}-0.001 \\
(-0.02)\end{array}$ & $\begin{array}{c}-0.001 \\
(-0.28)\end{array}$ \\
\hline LIQ & $\begin{array}{c}0.632 \\
(2.75)^{* * *}\end{array}$ & $\begin{array}{c}-0.008 \\
(-0.39)\end{array}$ & $\begin{array}{c}0.199 \\
(1.16)\end{array}$ & $\begin{array}{c}0.022 \\
(1.65)^{*}\end{array}$ \\
\hline R-squared & 0.128 & 0.456 & & \\
\hline F-Test/Wald test & $6.69 * * *$ & $38.13^{* * *}$ & $223.71^{* * *}$ & $398.18^{* * *}$ \\
\hline $\mathrm{AR}(1)$ test ( $\mathrm{p}$-value) & & & 0.247 & 0.142 \\
\hline AR(1) test (p-value) & & & 0.902 & 0.185 \\
\hline Sargan test (chi ${ }^{2}$ value) & & & 9.546 & 52.151 \\
\hline Sargan test ( $\mathrm{p}$-value) & & & 0.388 & 0.081 \\
\hline
\end{tabular}

Note: DV refers to the dependent variables. ${ }^{* * *}, * *,{ }^{*}$ refers to $1 \%, 5 \%$ and $10 \%$ level of significance. 
We find that the promoters, domestic institutional owners and foreign institutional owners have a significant positive impact on the ROA. This indicates that the presence of the promoters, domestic institutions and foreign institutions in the firms enhance the financial performance of the Indian companies. The current result is very much similar to the findings of Boone et al. (2011), Alipour (2013) and Desoky and Mousa (2013). In this study, we also detect that foreign institutional ownership has a significant positive impact on market capitalisation. This shows that investments from foreign institutions have highly enhanced market performance of Indian companies. This result is fairly reminiscent of Javid and Iqbal (2008) and Boone et al. (2011).

\section{Conclusion and Implications}

Empirical works based on ownership structure and its impact on firm performance have been limited and inconsistent when observed from the perspective of an emerging economy like India. Hence, in this study, we attempt to test the impact of ownership structure on Indian firms' corporate performance, post the US financial crisis of 2008. In our study, it is found that Indian listed firms have high ownership concentrations. This observation was also indicated by La Porta et al. (1999) who mentioned that most developing economies possess companies with concentrated ownerships. Despite the fact that high ownership concentration prevails in the Indian context, there seem to be no significant impact on firms' financial performance (ROA) although it has a negative impact on the market performance (MC). Based on this, it is deduced that large shareholders do not enhance firm performance, post US financial crisis 2008.

Our second model tests the causal relationship between ownership identities and the listed firms' performance. It is observed that the promoters, foreign institutional ownership and domestic institutional ownership have significantly boosted the financial performance of Indian companies, post the US financial crisis. This indicates that owners have strongly monitored the management and decision-making process to make their firms more efficient and profitable. Subsequently, it is also noted that only foreign institutional investments have significantly affected the market capitalisation of the Indian companies, post the US financial crisis. In this regard, it is inferred that the confidence and continuous investments from foreign institutions had assisted in propelling the investors' sentiments in the Indian market. 
From the results and findings generated, it is deduced that this study has made several contributions and implications. First, our study is based on the ownership structure in the Indian context, hence the outcome would be enriching the governance literature of the emerging markets. Further, the outcome would be beneficial to researchers, policymakers, managers and practitioners as they add to a better understanding of the corporate ownership structure in the Indian market. The findings of this study would also clarify the impact of ownership concentration and identities on the Indian listed firms' performance. The outcome generated may also ease policymakers need to formulate favourable policies, such as rewarding of tax incentives, hassle-free investment policy, insuring of investments, checking of fraudulent trading activities, proper monitoring of the listed firms' governance policies and ensuring the proper audit of firms' annual reports. These could induce investors' participation in the capital market. These results would be able to guide corporate managers in understanding the effect of ownership holdings on corporate performance, thereby motivating investors to better corporate performance. Finally, the equity investors would be able to understand the causes of the market performance variations; hence, they would be able to decide better on their investments or divestments.

\section{References}

Agrawal, A., \& Knoeber, C.R. (1996). Firm performance and mechanisms to control agency problems between managers and shareholders. Journal of Financial and Quantitative Analysis, 31(3), 377-397. http://dx.doi.org/ $10.2307 / 2331397$

Al Mubarak, M., \& Hamdan, A. (2016). The impact of corporate governance on market capitalization: Evidence from Bahrain Bourse. Corporate Ownership and Control, 13(3), 120-129. http://dx.doi.org/10.22495/cocv13i3p11

Alabdullah, T.T.Y. (2018). The relationship between ownership structure and firm financial performance: Evidence from Jordan. Benchmarking: An International Journal, 25(1), 319-333. http://dx.doi.org/10.1108/BIJ-04-20160051

Alipour, M. (2013). An investigation of the association between ownership structure and corporate performance: Empirical evidence from Tehran Stock Exchange (TSE). Management Research Review, 36(11), 1137-1166. http://dx.doi.org/10.1108/MRR-08-2012-0188

Aljifri, K., \& Moustafa, M. (2007). The impact of corporate governance mechanisms on the performance of UAE firms: An empirical analysis. 
Journal of Economic and Administrative Sciences, 23(1), 72-94. http://dx.doi. org/10.1108/10264116200700008

Al-Khouri, R. (2006). Corporate governance and firms value in emerging markets: The case of Jordan. Journal of Transnational Management, 12(1), 2549. http://dx.doi.org/10.1300/J482v12n01_03

Alonso-Bonis, S., \& de Andrés-Alonso, P. (2007). Ownership structure and performance in large Spanish companies. Empirical evidence in the context of an endogenous relation. Corporate Ownership and Control, 4(4), 206-216. http://dx.doi.org/10.22495/cocv4i4c1p5

Al-Saidi, M., \& Al-Shammari, B. (2015). Ownership concentration, ownership composition and the performance of the Kuwaiti listed non-financial firms. International Journal of Commerce and Management, 25(1), 108-132. http:// dx.doi.org/10.1108/IJCOMA-07-2013-0065

Anderson, R.C., \& Reeb, D.M. (2003). Founding-family ownership and firm performance: evidence from the S\&P 500. The Journal of Finance, 58(3), 13011328. http://dx.doi.org/10.1111/1540-6261.00567

Balasubramanian, B.N., \& Anand, R.V. (2013). Ownership trends in corporate India 2001-2011: Evidence and implications (Working Paper No. 419). Bangalore: Indian Institute of Management. Retrieved from http://dx.doi. org/10.2139/ssrn.2303684

Baltagi, B.H. (1995), Econometric analysis of panel data. Chichester, UK: John Wiley \& Sons.

Barnhart, S.W., \& Rosenstein, S. (1998). Board composition, managerial ownership, and firm performance: An empirical analysis. The Financial Review, 33(4), 1-16. http://dx.doi.org/10.1111/j.1540-6288.1998.tb01393.x

Barontini, R., \& Caprio, L. (2006). The effect of family control on firm value and performance: Evidence from continental Europe. European Financial Management, 12(5), 689-723.

Berle, A.A., \& Means, G.C. (1932). The modern corporation and private property. New York: Macmillan.

Boone, N., Colombage, S., \& Gunasekarage, A. (2011). Block shareholder identity and firm performance in New Zealand. Pacific Accounting Review, 23(2), 185-210. http://dx.doi.org/10.1108/01140581111163999

Breusch, T.S., \& Pagan, A.R. (1980). The Lagrange multiplier test and its applications to model specification in econometrics. The Review of Economic Studies, 47(1), 239-253. http:/ / dx.doi.org/10.2307/2297111

Carney, M., \& Gedajlovic, E. (2001). Corporate governance and firm capabilities: A comparison of managerial, alliance, and personal capitalisms. Asia Pacific Journal of Management, 18(3), 335-354. http://dx.doi.org/10.1023/ A:1010649828352

Chauhan, Y., Dey, D.K., \& Jha, R.R. (2016). Board structure, controlling ownership, and business groups: Evidence from India. Emerging Markets Review, 27, 63-83. http://dx.doi.org/10.1016/j.ememar.2016.03.003 
Chen, H., Hexter, J.L., \& Hu, M.Y. (1993). Management ownership and corporate value. Managerial and Decision Economics, 14(4), 335-346. http://dx.doi. org/10.1002/mde.4090140406

Cheung, Y-L., Rau, P.R., \& Stouraitis, A. (2006). Tunneling, propping, and expropriation: Evidence from connected party transactions in Hong Kong. Journal of Financial Economics, 82(2), 343-386. http://dx.doi.org/10.1016/ j.jfineco.2004.08.012

Chu, W. (2011). Family ownership and firm performance: Influence of family management, family control, and firm size. Asia Pacific Journal of Management, 28(4), 833-851. http:/ / dx.doi.org/10.1007/s10490-009-9180-1

Claessens, S., \& Fan, J.P. (2002). Corporate governance in Asia: A survey. International Review of Finance, 3(2), 71-103. http://dx.doi.org/10.1111/ 1468-2443.00034

Cronqvist, H., \& Nilsson, M. (2003). Agency costs of controlling minority shareholders. Journal of Financial and Quantitative Analysis, 38(4), 695-719. http:/ / dx.doi.org/10.2307/4126740

Deb, S.S., \& Chaturvedula, C.V. (2003). Ownership structure and firm value: empirical study on corporate governance system of Indian firms (SSRN Working Paper Series, 594221). http:/ / dx.doi.org/10.2139/ssrn.594221

Demsetz, H. (1983). The structure of ownership and the theory of the firm. The Journal of Law and Economics, 26(2), 375-390.

Demsetz, H., \& Lehn, K. (1985). The structure of corporate ownership: Causes and consequences. Journal of Political Economy, 93(6), 1155-1177.

Demsetz, H., \& Villalonga, B. (2001). Ownership structure and corporate performance. Journal of Corporate Finance, 7(3), 209-233. http://dx.doi.org/ 10.1016/S0929-1199(01)00020-7

Denis, D.K., \& McConnell, J.J. (2003). International corporate governance. Journal of Financial and Quantitative Analysis, 38(1), 1-36. http://dx.doi. org/10.2307/4126762

Desoky, A.M., \& Mousa, G.A. (2013). An empirical investigation of the influence of ownership concentration and identity on firm performance of Egyptian listed companies. Journal of Accounting in Emerging Economies, 3(2), 164-188. http://dx.doi.org/10.1108/20421161311320698

Douma, S., George, R., \& Kabir, R. (2006). Foreign and domestic ownership, business groups, and firm performance: Evidence from a large emerging market. Strategic Management Journal, 27(7), 637-657. http://dx.doi.org/ 10.1002/smj.535

Džanić, A. (2012). Concentration of ownership and corporate performance: evidence from the Zagreb Stock Exchange. Financial Theory and Practice, 36(1), 29-52. http://dx.doi.org/10.3326/fintp.36.1.2

Earle, J.S., Kucsera, C., \& Telegdy, Á. (2005). Ownership concentration and corporate performance on the Budapest stock exchange: Do too many cooks spoil the goulash? Corporate Governance: An International Review, 13(2), 254-264. http:/ /dx.doi.org/10.1111/j.1467-8683.2005.00420.x 
Fama, E.F. (1980). Agency problems and the theory of the firm. Journal of Political Economy, 88(2), 288-307.

Fan, J.P.H., Wei, K.C.J., \& Xu, X. (2011). Corporate finance and governance in emerging markets: A selective review and an agenda for future research. Journal of Corporate Finance, 17(2), 207-214. http://dx.doi.org/10.1016/j. jcorpfin.2010.12.001

Farooque, O.A., van Zijl, T., Dunstan, K., \& Karim, A.W. (2007). Ownership structure and corporate performance: Evidence from Bangladesh. AsiaPacific Journal of Accounting E Economics, 14(2), 127-149. http:/ / dx.doi.org/ 10.1080/16081625.2007.9720792

Fauzi, F., \& Locke, S. (2012). Board structure, ownership structure and firm performance: A study of New Zealand listed-firms. Asian Academy of Management Journal of Accounting and Finance, 8(2), 43-67.

Filatotchev, I., Lien, Y-C., \& Piesse, J. (2005). Corporate governance and performance in publicly listed, family-controlled firms: Evidence from Taiwan. Asia Pacific Journal of Management, 22(3), 257-283. http://dx.doi. org/10.1007/s10490-005-3569-2

Franks, J., \& Mayer, C. (2001). Ownership and control of German corporations. The Review of Financial Studies, 14(4), 943-977. http://dx.doi.org/10.1093/ rfs/14.4.943

Ganguli, S.K., \& Agrawal, S. (2009). Ownership structure and firm performance: An empirical study on listed mid-cap Indian companies. IUP Journal of Applied Finance, 15(12), 37-52.

Gaur, S.S., Bathula, H., \& Singh, D. (2015). Ownership concentration, board characteristics and firm performance: A contingency framework. Management Decision, 53(5), 911-931. http:/ / dx.doi.org/10.1108/MD-08-2014-0519

Gopalan, R., Nanda, V., \& Seru, A. (2007). Affiliated firms and financial support: Evidence from Indian business groups. Journal of Financial Economics, 86(3), 759-795. http://dx.doi.org/10.1016/j.jfineco.2006.09.008

Gorton, G., \& Schmid, F.A. (2000). Universal banking and the performance of German firms. Journal of Financial Economics, 58(1-2), 29-80. http://dx.doi. org/10.1016/S0304-405X(00)00066-0

Grossman, S.J., \& Hart, O.D. (1980). Takeover bids, the free-rider problem, and the theory of the corporation. The Bell Journal of Economics, 11(1), 42-64. http:/ / dx.doi.org/10.2307/3003400

Gunasekarage, A., Hess, K., \& Hu, A.J. (2007). The influence of the degree of state ownership and the ownership concentration on the performance of listed Chinese companies. Research in International Business and Finance, 21(3), 379-395. http:/ / dx.doi.org/10.1016/j.ribaf.2007.02.002

Haldar, A., \& Rao, S.N. (2011). Empirical study on ownership structure and firm performance. Indian Journal of Corporate Governance, 4(2), 27-34. http:// dx.doi.org/10.1177\%2F0974686220110203

Hausman, J.A. (1978). Specification tests in econometrics. Econometrica: Journal of the Econometric Society, 46(6), 1251-1271. http:/ / dx.doi.org/10.2307/1913827 
Hitt, M.A., Gimeno, J., \& Hoskisson, R.E. (1998). Current and future research methods in strategic management. Organizational Research Methods, 1(1), 6-44. http://dx.doi.org/10.1177\%2F109442819800100103

Hovey, M., Li, L., \& Naughton, T. (2003). The relationship between valuation and ownership of listed firms in China. Corporate Governance: An International Review, 11(2), 112-122. http://dx.doi.org/10.1111/1467-8683. 00012

Hu, Y., \& Izumida, S. (2008). Ownership concentration and corporate performance: A causal analysis with Japanese panel data. Corporate Governance: An International Review, 16(4), 342-358. http://dx.doi.org/10.1111/j.14678683.2008.00690.x

International Finance Corporation (2018). Corporate governance score: SEP BSE 100 companies. Washington DC: Author. Retrieved from https://www.ifc.org/ wps/wcm/connect/CG_Scores_S\%26P_BSE_100_Companies_Handbook. pdf

Jameson, M., Prevost, A., \& Puthenpurackal, J. (2014). Controlling shareholders, board structure, and firm performance: Evidence from India. Journal of Corporate Finance, 27(August), 1-20. http://dx.doi.org/10.1016/j.jcorpfin. 2014.04.003

Javid, A.Y., \& Iqbal, R. (2008). Ownership concentration, corporate governance and firm performance: Evidence from Pakistan. The Pakistan Development Review, 47(4), 643-659.

Jensen, M.C., \& Meckling, W.H. (1976). Theory of the firm: Managerial behavior, agency costs and ownership structure. Journal of Financial Economics, 3(4), 305-360. http://dx.doi.org/10.1016/0304-405X(76)90026-X

Jiang, P. (2004). The relationship between ownership structure and firm performance: An empirical analysis over Heilongjiang listed companies. Nature and Science, 2(4), 87-90.

Kang, D.L., \& Sørensen, A.B. (1999). Ownership organization and firm performance. Annual Review of Sociology, 25(1), 121-144.

Kang, J-K., \& Shivdasani, A. (1995). Firm performance, corporate governance, and top executive turnover in Japan. Journal of Financial Economics, 38(1), 29-58. http:// dx.doi.org/10.1016/0304-405X(94)00807-D

Kapopoulos, P., \& Lazaretou, S. (2007). Corporate ownership structure and firm performance: Evidence from Greek firms. Corporate Governance: An International Review, 15(2), 144-158. http://dx.doi.org/10.1111/j.1467-8683. 2007.00551.x

Kennedy, P. (2008). A guide to econometrics (6th ed.). Malden, MA: WileyBlackwell.

Kim, B-H., Kim, H., \& Lee, B-S. (2015). Spillover effects of the U.S. financial crisis on financial markets in emerging Asian countries. International Review of Economics \& Finance, 39(September), 192-210. http://dx.doi.org/10.1016/j. iref.2015.04.005 
Kogan, L., Ross, S.A., Wang, J., \& Westerfield, M.M. (2006). The price impact and survival of irrational traders. The Journal of Finance, 61(1), 195-229. http:/ / dx.doi.org/10.1111/j.1540-6261.2006.00834.x

Krishna, S., Ojha, A.K., \& Barrett, M. (2017). Competitive advantage in the software industry: an analysis of the Indian experience. In C. Avgerou \& G. Walsham (Eds.), Information technology in context: Studies from the perspective of developing countries (pp. 182-197). Aldershot: Ashgate.

Krivogorsky, V., \& Grudnitski, G. (2010). Country-specific institutional effects on ownership: Concentration and performance of continental European firms. Journal of Management \& Governance, 14(2), 167-193. http://dx.doi. org/10.1007/s10997-009-9097-6

La Porta, R., Lopez-de-Silanes, F., \& Shleifer, A. (1999). Corporate ownership around the world. The Journal of Finance, 54(2), 471-517. http://dx.doi. org/10.1111/0022-1082.00115

La Porta, R., Lopez-de-Silanes, F., Shleifer, A., \& Vishny, R.W. (1998). Law and finance. Journal of Political Economy, 106(6), 1113-1155. http://dx.doi. org/10.1086/250042

Leech, D., \& Leahy, J. (1991). Ownership structure, control type classifications and the performance of large British companies. The Economic Journal, 101(409), 1418-1437. http://dx.doi.org/10.2307/2234893

Liao, W-C., Shyu, J-C., \& Chien, S-M. (2014). A corporate life cycle analysis on the relationship between ownership structure and performance: Evidence from the Taiwan Stock Exchange. Asia Pacific Management Review, 19(2), 173-186. http:/ / dx.doi.org/10.6126/APMR.2014.19.2.04

Lichtenberg, F.R., \& Pushner, G.M. (1994). Ownership structure and corporate performance in Japan. Japan and the World Economy, 6(3), 239-261. http:// dx.doi.org/10.1016/0922-1425(94)90014-0

Loderer, C., \& Martin, K. (1997). Executive stock ownership and performance tracking faint traces. Journal of Financial Economics, 45(2), 223-255. http:// dx.doi.org/10.1016/S0304-405X(97)00017-2

Manawaduge, A.S., De Zoysa, A., \& Rudkin, K.M. (2009). Performance implication of ownership structure and ownership concentration: Evidence from Sri Lankan firms. Paper presented at the Performance Management Association Conference, Dunedin, New Zealand, April.

Manna, A., Sahu, T.N., \& Gupta, A. (2016). Impact of ownership structure and board composition on corporate performance in Indian companies. Indian Journal of Corporate Governance, 9(1), 44-66. http://dx.doi.org/ $10.1177 \%$ 2F0974686216635787

McConnell, J.J., \& Servaes, H. (1990). Additional evidence on equity ownership and corporate value. Journal of Financial Economics, 27(2), 595-612. http:// dx.doi.org/10.1016/0304-405X(90)90069-C

McConnell, J.J., \& Servaes, H. (1995). Equity ownership and the two faces of debt. Journal of Financial Economics, 39(1), 131-157. http://dx.doi.org/ 10.1016/0304-405X(95)00824-X 
Megginson, W.L., Nash, R.C., \& Van Randenborgh, M. (1994). The financial and operating performance of newly privatized firms: An international empirical analysis. The Journal of Finance, 49(2), 403-452. http://dx.doi. org/10.1111/j.1540-6261.1994.tb05147.x

Mehran, H. (1995). Executive compensation structure, ownership, and firm performance. Journal of Financial Economics, 38(2), 163-184. http://dx.doi. org/10.1016/0304-405X(94)00809-F

Mishra, R., \& Kapil, S. (2017). Effect of ownership structure and board structure on firm value: Evidence from India. Corporate Governance: The International Journal of Business in Society, 17(4), 700-726. http:// dx.doi.org/10.1108/CG03-2016-0059

Morck, R., Shleifer, A., \& Vishny, R.W. (1988). Management ownership and market valuation: An empirical analysis. Journal of Financial Economics, 20(Jan-Mar), 293-315. http:/ / dx.doi.org/10.1016/0304-405X(88)90048-7

Mukhopadhyay, J., \& Chakraborty, I. (2017). Foreign institutional investment, business groups and firm performance: Evidence from India. Research in International Business and Finance, 39(Part A), 454-465. http://dx.doi. org/10.1016/j.ribaf.2016.09.015

Muller-Kahle, M.I. (2015). The impact of dominant ownership: the case of AngloAmerican firms. Journal of Management \& Governance, 19(1), 71-89. http:// dx.doi.org/10.1007/s10997-013-9269-2

Omran, M.M., Bolbol, A., \& Fatheldin, A. (2008). Corporate governance and firm performance in Arab equity markets: does ownership concentration matter? International Review of Law and Economics, 28(1), 32-45. http:// dx.doi.org/10.1016/j.irle.2007.12.001

Park, K., \& Jang, S.S. (2010). Insider ownership and firm performance: An examination of restaurant firms. International Journal of Hospitality Management, 29(3), 448-458. http:/ / dx.doi.org/10.1016/j.ijhm.2009.10.023

Prowse, S.D. (1992). The structure of corporate ownership in Japan. The Journal of Finance, 47(3), 1121-1140. http://dx.doi.org/10.1111/j.1540-6261.1992. tb04007.x

Qi, D., Wu, W., \& Zhang, H. (2000). Shareholding structure and corporate performance of partially privatized firms: Evidence from listed Chinese companies. Pacific-Basin Finance Journal, 8(5), 587-610. http://dx.doi.org/ 10.1016/S0927-538X(00)00013-5

Shleifer, A., \& Vishny, R.W. (1986). Large shareholders and corporate control. Journal of Political Economy, 94(3, Part 1), 461-488.

Shleifer, A., \& Vishny, R.W. (1994). Politicians and firms. The Quarterly Journal of Economics, 109(4), 995-1025. http:/ / dx.doi.org/10.2307/2118354

Shleifer, A., \& Vishny, R.W. (1997). A survey of corporate governance. The Journal of Finance, 52(2), 737-783. http://dx.doi.org/10.1111/j.1540-6261. 1997.tb04820.x

Short, H., \& Keasey, K. (1999). Managerial ownership and the performance of firms: Evidence from the UK. Journal of Corporate Finance, 5(1), 79-101. http://dx.doi.org/10.1016/S0929-1199(98)00016-9 
Shyu, J. (2011). Family ownership and firm performance: Evidence from Taiwanese firms. International Journal of Managerial Finance, 7(4), 397-411. http://dx.doi.org/10.1108/17439131111166393

Smith, A. (1776). The wealth of nations, Modern Library Edition. New York: Random House.

Srivastava, A. (2011). Ownership structure and corporate performance: Evidence from India. International Journal of Humanities and Social Science, 1(1), 23-29.

Thomsen, S., \& Pedersen, T. (2000). Ownership structure and economic performance in the largest European companies. Strategic Management Journal, 21(6), 689-705. http://dx.doi.org/10.1002/(SICI)1097-0266(200006) 21:6\%3C689::AID-SMJ115\%3E3.0.CO;2-Y

Wang, J., Guthrie, D., \& Xiao, Z. (2012). The rise of SASAC: Asset management, ownership concentration, and firm performance in China's capital markets. Management and Organization Review, 8(2), 253-281. http://dx.doi. org/10.1111/j.1740-8784.2011.00236.x

Welch, E. (2003). The relationship between ownership structure and performance in listed Australian companies. Australian Journal of Management, 28(3), 287-305. http://dx.doi.org/10.1177/031289620302800304

$\mathrm{Xu}, \mathrm{X} .$, \& Wang, Y. (1999). Ownership structure and corporate governance in Chinese stock companies. China Economic Review, 10(1), 75-98. http:// dx.doi.org/10.1016/S1043-951X(99)00006-1

Yammeesri, J., \& Lodh, S. C. (2004). Is family ownership a pain or gain to firm performance. Journal of American Academy of Business, 4(1/2), 263-270.

Zeitun, R., \& Gang Tian, G. (2007). Does ownership affect a firm's performance and default risk in Jordan? Corporate Governance: The International Journal of Business in Society, 7(1), 66-82. http://dx.doi.org/10.1108/ 14720700710727122 
